\title{
Beyond programmatic versus patrimonial politics: Contested conceptions of legitimate distribution in Nigeria
}

\author{
PORTIA ROELOFS \\ LSE Fellow, LSE, Houghton Street, London WC2A $2 A E$ \\ p.roelofs@1se.ac.uk
}

\begin{abstract}
Accepted for publication in Journal of Modern African Studies $12^{\text {th }}$ March 2019. Forthcoming in 57:3 Autumn 2019.
\end{abstract}

\begin{abstract}
:
This article argues against the long-standing instinct to read African politics in terms of programmatic versus patrimonial politics. Unlike the assumptions of much of the current quantitative literature, there are substantive political struggles that go beyond 'public goods good, private goods bad'. Scholarly framings serve to obscure the essentially contested nature of what counts as legitimate distribution. This article uses the recent political history of the Lagos Model in southwest Nigeria to show that the idea of patrimonial versus programmatic politics does not stand outside of politics but is in itself a politically constructed distinction. In adopting it a priori as scholars we commit ourselves to seeing the world through the eyes of a specific, often elite, constituency that makes up only part of the rich landscape of normative political contestation in Nigeria. Finally, the example of a large-scale empowerment scheme in Oyo State shows the complexity of politicians' attempts to render distribution legitimate to different audiences at once.
\end{abstract}

\section{$\underline{\text { Acknowledgements: }}$}

I am grateful to the ESRC for funding the doctoral fieldwork on which this paper is based. Additonal fieldwork was supported by the London School of Economics Department of International Development Research Infrastructure and Investment Funding (RIIF). Thanks must go to Olubukola Olayiwola and Joseph Ayodokun for astute research assistance. I'm grateful to James Putzel, Benjamin Chemouni, Pritish Behuria and Elizabeth Storer for comments on earlier iterations of this paper. Conversations with Kate Meagher and Sa'eed Husaini were instrumental in refining the ideas for the paper. I would also like to thank two anonymous reviewer for suggestions that allowed me to make my arguments more precise. 


\section{INTRODUCTION: THE SHIFTING DIVIDE BETWEEN LEGITIMATE AND ILLEGITIMATE DISTRIBUTION}

'This government is so insensitive, lacks human face and basically they are clueless. [The Governor] his supporters say 'If you go to the poultry you won't believe how clean it is' and we ask 'what is the magic?' and we check, the poultry is clean but the chicken are not there! ... He forgets all the time that being in government is about serving the people.'

Teslim Folarin, Gubernatorial Candidate for the People's Democratic Party, Oyo

State

"There are a billion poor people in the world. Why don't we just find the poor and give them one dollar a week and do nothing else. No questions asked. What they do with the money is not our concern. That would probably do more to relieve poverty than anything else."

\section{Meghnad Desai, director of the London School of Economics Centre for the Study of Global} Governance, 2003. ${ }^{i i}$

All politics involves distribution. Indeed, many would claim that politics is at its heart about controlling distribution: who gets what, when and how. Whether a particular distributive decisions are perceived as legitimate depends to a large extent on how they are framed by normative ideas. Some of these norms are so widely shared as to be taken for granted, whereas others are subject to disagreement. Policies and programmes that fall in this grey zone present a window onto fundamental debates over the role of the state and the aims of development. For example, in January 2019 opposition parties and civil society groups in Nigeria condemned a federal government empowerment scheme as "sophisticated voterinducement" ("TraderMoni is vote buying, says Transparency International," 2019). The TraderMoni scheme, launched in 2016 and implemented by the Bank of Industry disbursed collateral free loans totalling N12 billion to over a million recipients. Even among its opponents, the grounds on which the scheme was judged to be illegitimate varied: it was too close to the election, it was not in the party's manifesto or it constituted the use of public funds for party-specific aims ("Saraki to FG," 2018). Thus the question of how to draw the line between legitimate distributive strategies that win votes and illegitimate vote-buying strategies is a live topic in Africa's biggest democracy.

Unsurprisingly, where to draw the line between legitimate and illegitimate distribution is highly political: as seen in archetypal left-right debates over taxation and the legitimacy of the market as a mechanism for distribution. Distributive strategies can be evaluated according to whether they are instrumentally valuable - do they bring about desirable outcomes? - as well as intrinsically, in light of the principles or values they embody. These theoretical complexities also play out in negotiations of patronage's normative framing at the microlevel. Voters may regard material goodies given as patronage "as pieces of information that reveal the positive personal qualities of the giver, such as generosity, politeness, responsiveness, and respect..." or else demonstrating a "personal defect on the part of the giver, such as arrogance and disrespect." Depending on its normative framing, vote-buying can be either a virtue or a vice (Schaffer and Schedler, 2007, p. 17).

The normative fluidity of distributive strategies is not simply an esoteric aspect of popular politics. Even within the development industry, which is characterised by less overtly political and more technocratic approaches, ideas about what constitutes legitimate distribution have changed over time. The most notable recent shift has been with regards to direct cash transfers. Whilst an acceptance of the need for social protection has come to 
occupy a central plank in development thinking as part of a "quiet revolution" (Barrientos and Hulme 2009) it is worth remembering just how controversial this was when it was first suggested. In 2004, Joseph Hanlon (2004) asked in a leading development journal "Is it possible to just give money to the poor?" His claim that yes it is possible and, what's more, advisable, was intentionally provocative. Whilst cash transfers and wider social protection schemes are now a regular component of mainstream development programmes, at the time they went against the reigning wisdom of how money should be spent and by whom, with attendant beliefs about the deservingness and rationality of the poor.

This article interrogates how certain distributions come to be legitimate by reconsidering a conceptual framework that has been highly influential in scholarly understandings of African politics: patrimonial versus programmatic politics. I argue that this lens is just one possible conceptual tool among many. It foregrounds some aspects of Nigeria's political development whilst obscuring others. This conceptual division - and the concomitant normative judgement about which sorts of distribution are legitimate - has been naturalised into the political vision of progressive Yoruba politicians in the southwest who since the 2000s have promoted what I call the 'Lagos Model'. The same lens mean that certain distributive strategies in which Nigerian leaders regularly engage - namely the direct distribution of food, money and material goods, known in Oyo State as amala politics - were rendered unacceptable, apart from where they facilitated programmatic change. Debates over the package of distributive options both permitted and foreclosed by the Lagos Model represent a continuation of longrunning contestation within Yoruba political history, extending to patterns of leadership established under the Old Oyo Empire, over what constitutes legitimate distributive strategies.

De-naturalising the programmatic versus patrimonial distinction allows us to better understand the dynamics shaping politics around the 2015 gubernatorial election. First I show how the Governor and his party sought to reconstitute politics in Oyo State through the framing of patrimonial versus programmatic politics, and to present themselves as embodying the latter. I show how the boundaries of legitimate distribution is in itself subject to political contestation. Distributive programmes that sat uncomfortably with Ajimobi's stated aim to deliver programmatic politics became an essential part of his efforts to garner popular support. The same concrete acts of material distribution were simultaneously framed in two opposing ways, each implying different claims about what distributive strategies are legitimate. Those distributive elements which were too reminiscent of patrimonial politics to survive re-framing for international audiences were strategically hidden. My analysis draws on a total of 6 months in-depth qualitative fieldwork over two trips, first in October December 2013 and then April - August 2015. I conducted over 150 focus groups and interviews with traders, civil servants, politicians and others in a mixture of Yoruba, English and Pidgin, assisted at times by tri-lingual research assistants. A smaller number of follow up interviews in July 2018 - when Ajimobi was 3 years into his second term - allowed me to test my conclusions with my informants. Finally I return to the current scholarship on programmatic politics and highlight how programmatic politics restricts the distributive options open to African governments. Whereas discourse is often seen as simply concerned with 'valence issues', this article points to news ways in which normative politics in Nigeria reflects debates over essentially contested notions of development, the state and legitimate distribution.

\section{Theorising distribution and good politics in Africa}

The question of what sort of distributive strategies are legitimate takes on heightened importance in the study of politics in Africa. Though different methodologies utilise different 
conceptual vocabularies, implicit conceptions of good and bad politics typically rely on a division between legitimate and illegitimate distribution. It is worth sketching the stylised assumptions of these approaches, before opening up to the increasing nuance with which they are operationalised. Drawing on the language of neo-classical economics, quantitative political scientists divide distributive strategies into those providing private goods - typically small-scale goods for private consumption - and public goods from which citizens can derive long-term generalised benefits. Political systems are then evaluated depending on the relative prevalence of each in of electoral appeals (Vicente and Wantchekon, 2009). Where politicians compete to deliver public goods they embody values of accountability, competition and responsiveness. Democracy is thus valuable because it provides a system for 'making politics work for development' (World Bank, 2016). Distribution of private goods is illegitimate not only because of the opportunity cost of spending on public goods but because it short-circuits democratic accountability through vote-buying (Lindberg, 2013).

Researchers rooted in political economy, sociology and anthropology invoke concepts like clientelism, patronage politics and (neo-)patrimonialism to problematize the way that personalistic authority structures undermine whole political systems (Bratton and van de Walle, 1994). The more sympathetic accounts locate the origins of patrimonial politics in 'moral economies' whereby the Big Men are legitimate on the basis of communal or affective values (Olivier de Sardan, 1999). On this view, thus patrimonial distribution may have its own internal logic by which it reflects important values, but these are conceived as being incompatible with modern democracies as well as leading to ultimately anti-developmental consequences. For example, Jeffrey Paller (2014, p. 123) highlights the informal values of friendship, capitalist entrepreneurship, family, and religion to show that patrimonial politics is not devoid of values, as might be suggested the economistic literature that treats private goods distribution as necessarily an obstacle to accountability. However, regardless of how intrinsically valuable these informal practices are, for Paller they still pose a threat to democratic values properly understood. In contrast to patrimonialism, programmatic politics is seen as a more legitimate way of marrying distributive strategies with democratic accountability (Nic Cheeseman, 2014). Voters should choose between rival parties on the basis of substantive public programmes that they promise to implement. Whilst sharing the same basic idea as the economists divide between public and private goods, a focus on programmatic politics gives a much richer account of the broader organisational environment this requires and it recognises that different voters will prioritise different sorts of public goods for instance trading off roads for hospitals (Sanches, 2018).

Of course these schematic simplistic binaries of public goods versus private goods, and patrimonial versus programmatic politics belies considerable nuance within the corresponding literatures. At the macro-level, there is a recognition that under certain condition patrimonial politics can be 'hacked' and put to the service of more programmatic objectives. The possibility of 'developmental patrimonialism' in places like Rwanda suggests that patrimonialism can act as an instrument for centralising rents and channelling patronage into long-term investments (Booth and Golooba-Mutebi, 2012). Mushtaq Khan's work on political settlements accepts patrimonial politics as a fact of life in many countries in the global South (Khan, 2005). This opens the possibility that patronage can be legitimate insofar as it is productive. Such pragmatism was part of a wider shift in development studies towards accepting that patronage could be productive under certain conditions. Whether under the banner of 'good enough governance' (Grindle, 2004), 'going with the grain'(Kelsall, 2011) or a pragmatic embrace of 'what works' (Hossain, 2007), scholars and practitioners become more accepting of regimes that that deviate from purely programmatic criteria but deliver the goods. Together these show that whilst patrimonialism is not intrinsically desirable it is 
possible for it to be instrumentally useful. Similarly, analyses of 'electoral clientelism' show how democratic competition be sustained alongside patrimonialism (Kramon, 2017).

At the same time there has been increased attention in political science to "the nuts and bolts of African politics" (Lindberg, 2010, p. 118). Fine-grained empirical studies reveal that mechanisms associated with patron-client relations may nonetheless be harnessed by citizens to demand public goods. Voters in Niamey, Niger engage in personal contact with their representatives, through visits and phone calls, but use that private contact to make programmatic requests (Mueller, 2018, p. 44). Alternatively, clientelistic demands may be met with programmatic responses: in Ghana "the intense pressures for ... strictly private needs can lead office holders to provide collective goods" as a more sustainable solution (Lindberg, 2010, p. 137). Even where politicians do distribute private goods in advance of elections this doesn't always serve to 'short-circuit' the demand for public goods, but may function as a signalling device to show that the candidate has the requisite means and status to deliver if elected (Gadjanova, 2017). Thus the division of legitimate and illegitimate distribution remains the line between public and private goods, but this can be incorporated into a considerably more contextualised analysis of how politics works on the ground in African countries.

Notwithstanding these debates among scholars of patrimonial politics, there remains an underlying consensus of where to draw the line between legitimate and illegitimate distributive strategies. This is despite the recognition in development studies more broadly that this division is both contested and liable to shift over time. As shown by the shifting status of social protection and cash transfers, what looks like a wasteful frittering away of public funds in the hands of the undeserving poor under one development regime, is a transformative social protection programme in another. If we are to apply this insight to the study of African politics we open up the possibility that practices currently seen as patrimonial - including the allocation of small scale goods for private consumption - could emerge as legitimate distributive strategies: not because patrimonialism is in fact OK but because the practices in question defy the implicit normative distinctions of the patrimonialism label.

\section{Distributive politics in southwest Nigeria in historical context}

\section{Historical debates over legitimate distribution:}

The political history of Yorubaland can be charted in a series of tussles over the distributive duties of leaders From pre-colonial times, the norms of leadership dictated that not only should leaders be military figures, but they should cultivate a following of clients, through their patronage and generosity. The "gaze" of followers confers ola a form of social honour or authority (Watson, 1998, p. 467). Traditional oriki poetry and proverbs reflect norms of generosity and the importance of leaders sharing their wealth. An oriki from 1871 remarks about one leader that "there's always something to eat in [his] house" and of his followers who eat from his 'thousands of plates' in his kitchen (Watson, 2000, p. 477). The English translation of a Yoruba proverb re-affirms these values: one cannot be tight-fisted (selfish), and be endowed with honour (Omobowale and Olutayo, 2007, p. 432). Of course, ideas about legitimate distribution were contested. Yet money has negative associations too, "as a destabilizer and corrupter" (Agbaje, 2002, p. 5). Through Ibadan's history its populace has been cautious about the generosity of wealthy leaders, on the basis that acceptance of patronage should not oblige the populace to support irresponsible leaders (Barber, 1995; Guyer, 1995). Omobowale and Olutayo (2010, p. 459) argue that in Yoruba society patrons are chosen not only on the basis of their financial clout but also their good character, based on "philanthropic deeds and wisdom." What a patron is able to provide materially is closely 
intertwined with what they can contribute emotionally, and in terms of advice and playing being a good baba-isale or role model (Omobowale, 2008). Therefore whilst leaders are expected to share economic benefits, this must be done appropriately, and patronage cannot trump accountable leadership. Moreover, distribution monopolise the expectations of the duties of power, with distributive norms sitting alongside and often in tension with demands for progress and the need for leaders to rise up through the correct channels that might guarantee their integrity.

By the mid twentieth century two broad lines of politics had been established. On one side were conservative populists who placed direct distribution at the centre of their conception of good governance. Populist godfather figures since the 1950s are described as 'people-based' leaders who 'operated an open door policy' (Adeyemo, 2008). One of the recurring motifs of accessibility in these historical accounts is of the leader eating with his lowly followers. In the 1950s as Chairman of Ibadan District Council and later the leader of the opposition in what was then the Western Region, Adegoke Adelabu, 'stooped to take meals and drinks communally with his admirers in side-sheds and market stalls' (Layonu, 2003, p. 107). Whilst such norms tend to be associated with 'moral economies' of affection and interpersonal obligation, here they took shape in inescapably political contexts: leaders with largescale jurisdictions backed up by state power. As explained by Gavin Williams in his account of Ibadan politics in the 1940s the obligation for leaders to engage in direct distribution was evidence of popular negotiations of the material inequalities of power and resources brought about by the modern state. Adelabu's support base was among the socially excluded mekunnu - cocoa workers. The 'mekennu' movement renounced the power of Western education as a means of controlling state resources and the inequality that resulted. He promised to "secure for the small man the favours that were monopolized by the (predominantly educated) 'big men"'. Throughout the 1990s and 2000s Lamidi Adedibu became the most powerful figure in Oyo state, distributing daily bowls of amala and gbegiri, via a followership comprised on mass grassroots associations: social groups, religious unions and trade unions (Omobowale and Olutayo, 2010, p. 454; Animasawun, 2013, p. 15). Adedibu, was celebrated for the way he embedded the material fact of patronage in a legacy of norms and values (Omobowale and Olutayo, 2007; Timothy, 2008).

The second major line consisted of progressives who rejected this conception of distribution, casting it as backward and personalistic. For progressives like Obafemi Awolowo, first Prime Minister of the Western Region, the duty of government was to the resources over which the state had control and distribute them in ways that transformed society and the individuals within it. Awolowo combined progressive politics with Yoruba cultural nationalism: his party, the Action Group, enacted this vision of enlightened leadership and transformative social policy built on the idea of olaju (Peel, 1983, p. 159). Among this group Yoruba identity became consolidated as 'inherently modern' and 'progressive' (Adebanwi, 2014, p. 59) whereby their collective characteristics as outward-looking and sophisticated would be the basis for transcending the political stagnation represented by the likes of Adegoke and Adedibu.

Thus for the progressives the lens of patrimonial versus programmatic politics was a snug fit with their political worldview. For the populists, it is at best a misunderstanding of the realities of inequality that result from power, and at worst a cynical ploy to fence off the benefits of state power by elites who don't trust their poorer compatriots. Politicians from both populist and progressive camps in southwest Nigeria have always been forced to innovate in response to the failures of their rivals. Following democratisation in 1999, progressive controlled the state for 4 years under the banner of Action Congress before the 
People's Democratic Party (PDP) took over from 2003 to 2011. PDP candidates backed by Adedibu capitalised on grievances with elite-driven long-term development policies that ignore popular demands for more immediate distribution of economic benefits in the face of widespread poverty (Adebanwi, 2005, p. 20; Hoffmann and Nolte, 2013). Rashidi Ladoja and Christopher Adebayo Alao-Akala presided over growing public disorder as the capital, Ibadan, gained a reputation for violent street battles and 'godfatherism'. Whilst Ladoja eventually forged a career independent of Adedibu's support, Akala earned the nickname 'ATM' and was widely seen as a caricature of the distributive ideals. A common remark I heard during my fieldwork in 2013 and 2015 was that he was a scoundrel but at least during his time in office money was flowing. Support for amala politics does not mean it is blindly accepted as good politics, but it reflects a grudging acceptance of a form of politics that offered some minimal concessions to material reality in which people live and the normative values through which governments must demonstrate their sensitivity to that reality.

Punctuating this history were periods of military rule and dictatorship. As the military handed over to a civilian government in 1998 and prepared for democratisation, Yoruba politicians from the pro-democracy movement saw the chance to assert the dominance of the progressives once and for all. Just as the scholarly lens of programmatic versus patrimonial politics sees the latter as destined to fall away in the face of mounting modernisation and institutionalisation, this band of politicians saw their role as ushering in a fateful return to politics as it always should have been: 'Awo' politics.

\section{Rupture from Amala politics: contesting the legitimacy of distributive legacies in Nigeria's southwest}

Under the banner of the Action Congress a handful of progressive governors were elected across the former Western region in 1999 (Adebanwi, 2014). The most striking case of transformation however was in Lagos. Two consecutive progressive governors managed to effect developmental reforms against the back drop of urban crisis and government failure. In particular, this transformation has won plaudits for not only achieving improvements in urban conditions but in apparently transforming the mode of governance, which has long been understood to be at the heart of Nigeria's frustrated development. ("Africa: Lessons from Lagos," 2012, "International: A rare good man; Nigeria's business capital," 2011) The 'Lagos model' that emerged was one of technocratic service-delivery state pursuing privatesector driven development. In the space of a decade there were radical and visible improvements in waste collection, security and public infrastructure.

The 'new' technocratic mode of governance was not dogmatically tied to the progressives programmatic aims however. Existing scholarly analyses highlight the skill with which Bola Tinubu, first as governor and then as sponsor of his protegee and former chief of staff Babatunde Fashola, managed elements of patronage, side payments to key groups and delivery of immediate economic benefits to the population (Fourchard, 2011; de Gramont, 2015). For example hoodlums known as 'area boys' were absorbed into a newly formed division of traffic police to enable a security crackdown. These less technocratic elements were mobilised to overcome resistance and build support for longer-term developmental state-building projects such as expanding the tax base and tax compliance (LeBas and Cheeseman, 2013). In this way, Lagos is an example of the way that the framework of programmatic versus patrimonial politics layers on to the normative framing of Lagos Model politicians themselves, as well as capturing the way that patronage can be 'hacked' and put to the service of programmatic aims (Cheeseman and de Gramont, 2017). 
Indeed, across the southwest, progressive Yoruba politicians sought to replicate the Lagos Model in their own states. In addition to sharing core policy tenets, like a focus on physical infrastructure, public sector reform and pro-investor policies, they shared a common framing of programmatic versus patrimonial politics through which they narrated their political struggles. The ongoing struggles between the two major protagonists of Ekiti state politics from 2003 seemed to confirm the story of the southwest as programmatic versus patrimonial politics. Dr Kayode Fayemi was the epitome of programmatic politics: as candidate first for the ACN from 2013 the All Progressive's Congress (APC) he reflected the Lagos Model's most internationally palatable elements, having emerged from the world of civil society to be a beacon of good governance. Flagship policies included improving internet connectivity, improving Ekiti's standing in the Ease of Doing Business Index and numerous partnerships with international donors (Ugwuanyi, 2014). By contrast Ayodele Fayose of the PDP was described as 'the apotheosis of Adedibu' (Ifowodo, 2014). From Fayose's first election to the governorship in 2003 the two faced each other in every subsequent gubernatorial election, and repeated legal tussles over contested results. In a profile of Ekiti state the New York Times in described the situation surrounding the 2007 election in the following Manichean terms: "Mr. Fayemi's campaign treads the treacherous middle ground between the high road, on which pro-democracy advocates have traditionally marched directly to defeat, and the bruising, money-driven politics that dominate Nigeria's electoral contests." The mainstream interpretation was that there were a virtuous minority of politicians, like Ekiti's Dr Fayemi, who knew what good governance looked like: "the high road". Yet, they were forced to make concessions to "money-driven politics" despite it making them "uncomfortable', because, as Fayemi said, "this is what we live with." (Polgreen 2006)

In line with Fayemi's diagnosis of being caught between 'the high road' and 'money politics' progressive politicians from the same party in Oyo sought a 'rupture' with the past and spoke of their radically transforming the basis of politics in the state. Much of this rupture was defined with regards to norms of distribution. Drawing on his travels abroad and career spent working in a multinational oil company, the new APC governor, Abiola Ajimobi, promised a break with amala politics and build legitimacy instead through modernising Oyo State (OSG Website, 2013, 2015). Oyo State, though less studied than Lagos State, presents the dilemmas of how to mix the politics of principle with patronage even more starkly than the more studied Lagos state. Ajimobi adopted the package of policies that had worked so well in Lagos as a way of pursuing principled politics based on a vision of dis-embedding the state from patronage demands to pursue progress in the long-term. Compared with Lagos which hosts the headquarters of major regional banks and firms, Oyo state was much more economically vulnerable. With around $6 \%$ of the government revenue of its more cosmopolitan cousin, the Oyo state government was confronted with the rough edges of the trade-offs and difficult decisions posed by political transformation.

Ajimobi and the political elites who backed him generally shared an ideologically driven opposition to the idea of the state as a provider. A member of Ajimobi's campaign team in Ibadan explained that direct transfers to the poor were a moral hazard, by receiving something for free people would become lazy and unproductive. ${ }^{\text {iii }}$ A senior official closely linked to Ajimobi's party, explained the problem as he saw it: 'Oyo, over the years they've been used to a "something for nothing government" where they don't offer anything in return. 'iv Ajimobi's Ajumose slogan summarised the belief that it was inappropriate for government to simply 'do things for' the people, rather state and society should do thing together, in partnership. Upon his election, Ajimobi built on the progressive politics of Obafemi Awolowo (Adebanwi, 2014, pp. 224-5). Where Awolowo, known as 'the Sage' had 
pioneered universal education and modern development in the 1960s, Ajimobi built his appeal on a promise of progress in the $21^{\text {st }}$ century. This centred on a transformation of the state's urban environment, which he achieved through urban renewal policies, including the demolition of thousands of roadside stalls, new roads and modern markets and a flagship flyover in the centre of the state capital ("Tinubu, Akande, Rochas rejoices with Ibadan on projects Commissioning.," 2013). Progressive politicians in Oyo not only mobilized the implicit contrast between programmatic and patrimonial politics because they knew it would play well internationally - which it did - but because they harboured strong personal commitments to the underlying division between legitimate and illegitimate distribution that it embodies. They campaigning involved an attempt to change the mindsets of their constituents to make them accept that amala politics was in fact patrimonial, and as such should no longer be seen as an appropriate demand upon government. Articulated most clearly in a public address in 2014 Ajimobi's vision of legitimate leadership was that a 'good leader takes people to where they want to be', i.e. distributes patronage, but 'a great leader takes them where they ought to be', i.e. progressive programmatic politics (Oladele, 2014).

However, three years in to Ajimobi's first term, political happenings in Ekiti raised the possibility that the lens of programmatic versus patrimonial politics was insufficient both as a political strategy and as an analytical device. Once Fayemi came to office in 2007 it was largely assumed that he would replicate the electoral success seen in Lagos. However, in July 2014 after a four year term to showcasing what programmatic politics had to offer, Fayemi lost to Fayose (Akinrefon, 2014). Debates over how to interpret Fayose's electoral appeal centre on his policy of "stomach infrastructure" whereby he gave out bags of rice and live chickens often accompanied by great media fanfare. On one view this was simply fulfilment of Fayemi's pessimism, and an example of the distribution of private goods short circuiting democratic accountability and impeding the provision of public goods. However, others have shown how this distribution of immediate material benefits to the masses was electorally successful because it was understood by voters as signalling that Fayose would be attentive to their everyday concerns compared with an out of touch Fayemi who's infrastructural reforms were weighted too far in favour of long-term future pay-off. Indeed, the term 'stomach infrastructure' itself shows that the systematic and large-scale promises of programmatic politics were not being ignored per se: rather, it makes the claim that the infrastructure that mattered is that which people would benefit from immediately. This highlights the risks of treating patronage as something that can simply be added to an otherwise programmatic platform to buy support for reforms, as in the standard account of Lagos Husaini's ethnography of party loyalists show that some who received pre-election patronage from Fayemi found it disrespectful that at the last minute they had tried to buy their support despite, and choose to back Fayose as the more trust-worthy candidate (Husaini, 2018). If patronage is used as a tactic to top-up waning legitimacy for a programmatic agenda that is otherwise seen as out of touch, it risks backfiring and heightening the perceived 'arrogance' of a distant leader.

In Oyo state opposition politicians contested not only the casting of amala as illegitimate, but questioned the legitimacy of the patterns of distribution that resulted from the more programmatic elements of Ajimobi's policies such as urban renewal. This contestation involves not only claims to the legitimacy of what dominant scholarly frameworks would cast as patrimonial politics, but also the wholesomeness of those distributive strategies that are glossed as programmatic and thus legitimate. Six months before the 2015 gubernatorial election in Oyo a major Nigerian newspaper reported that the governor would lose because 'people will not vote for roads but what directly affects their lives', where roads symbolised 
Ajimobi's emphasis on modern infrastructure ("The APC Government in Oyo State is gone Senator Lekan Balogun," 2014). People described Ajimobi as having no 'human face', and not being 'people oriented' (Esan, 2012; Amusat, 2015). A senior member of the PDP in Oyo State claimed that the governor had forgotten that leaders must have 'empathy' and 'strive to alleviate the sufferings of the people by providing palliatives', citing the role of alms-giving in Islam and Christianity (Taiwo, 2014). Whilst Ajimobi pursued a vision of principle without patronage, there were viable and well-resourced contenders who were willing to meet the unmet demand for a more caring leader. Political debate in the run up to the 2015 election shows that people read Ajimobi's resistance to giving out patronage and his refusal to honour the legacy of leaders who showed human face as him not caring for his citizens. Ajimobi's principled modernising agenda became unpopular (Atoyebi, 2014) as key policiesincreasing taxes on shop signs, demolishing tens of thousands of roadside shops without compensation, and fining people for 'environmental offences' of waste dumping - imposed short term costs on the electorate (Ajayi, 2014). Urban renewal in particular drew much popular criticism. One opponent framed it as 'neglecting the masses in favour of plants and flowers' and urged voters to back his rival party 'for deliverance from an insensitive government' (Adekanmbi, 2013). When Ajimobi was in power, the memory of populist leaders was very much alive in Ibadan. Even 50 years after his death, Adelabu was still remembered fondly on the streets of Ibadan as a 'political patron who ministered to the needs of the downtrodden' (Omobowale and Olutayo, 2010, p. 453). The most powerful rivals to Ajimobi in the 2015 election had close ties with Adedibu ${ }^{\mathrm{v}}$ and drew on this symbolic legacy of patronage embedded in and expressing normative values of 'human face' to challenge the legitimacy of Ajimobi's agenda.

Overall, the governor's team seriously feared losing the 2015 election and had to re-evaluate the distributive effects of their policies. (Adekanmbi, 2015) Ajimobi's spokesman explained how the perception of taxation being heavy, for example, was a threat to their re-election: 'We had to swim out of it by telling people that 'look you cannot have development unless...' But at the same time, we are being very careful in terms of imposing taxation on the people. ${ }^{\text {vi }}$ Moreover, the resources available to Ajimobi fell substantially in the final months of 2014. ${ }^{\text {vii }}$ From late 2014 the state government in Oyo was unable to pay salaries, let alone expand the distribution of resources. The governor had to find ways of responding to popular discontent over his efforts recast the obligations of government away from direct distribution. Resulting policies had to be framed in appropriate local norms of distribution without threatening the state government's reputation with investors as a fiscally responsible (Oxford Business Group, 2013).

\section{EMPOWERMENT EVENTS IN OYO}

Since the beginning of his political career Ajimobi has run 'empowerment projects' of his own, out of a vocational training centre he had been running since the time when he entered the Senate in 2003. ${ }^{\text {viii }}$ As Governor, Ajimobi needed to engage in empowerment on a much larger scale. Immediate benefits were distributed by the state government and ruling party to select political constituencies though this required careful recalibration of the framing for different audiences. Each framing reflected a different conception of what sorts of distribution were legitimate.

\section{Loans to traders: Managing multiple framings of legitimate distribution}

In 2013, the APC in Oyo State started building up a network of associations called the Ajumose Coalition Movement (ACM) as part of APC electioneering efforts. The ACM was made up of pre-existing social and informal economic organisations that agreed to ally with the APC, and campaign for them around the election in exchange for access to some benefits. 
By late 2014 the movement had 168 membership groups, including the Oyo branches of the National Carpenters Association, the Nigerian Barbers, the Butchers Association, and a hairdressers' association. Ajimobi used this network to deliver interest-free loans, totalling $\mathrm{N} 300 \mathrm{~m}$ to market traders in advance of the election. The Governor and his team often referred to the loans as evidence of his ability to deliver empowerment to the grassroots (Ogunyemi, 2015) and thus counteract claims that his government had only helped the elites.

Every stage of the process, from the initial pledge to the disbursement, was attended with extensive news coverage and publicity. In December 2013, Ajimobi made promises to the traders, at what was described in the news as an 'interactive stakeholder meeting'. Six market associations were to get $\mathrm{N} 50 \mathrm{~m}$ each (Jegede, 2013). The promised funds were delivered a year later, at a ceremony at Lekan Salami Stadium that was broadcast by Channels Television. Six thousand traders attended (Johnson, 2014). The event featured singing, music, dancing and photo opportunities of the Governor handing out giant cardboard cheques.

The event was framed in a way that balances the idioms of popular conceptions of good governance, with statements tying the government to the Lagos Model's agenda of private sector-led development. On Channels TV the reporter's voice-over explains how this program is not focused on consumption but aimed at larger processes of economic growth: 'These traders now have a stronger capital base, and this is expected to transform their businesses'. The Special Adviser to the Governor on Trade and Investment said the programme 'will drive the state forward and bring inclusive and sustainable development' (Channels TV, 2014). The logic of group patronage (Omobowale, 2008) - giving the loans in lump sums to six supportive organisations - was re-framed in official discourse as a developmental targeting of marginalised and vulnerable individuals with loans that had transformative economic potential. For example, a representative of the Central Bank of Nigeria linked the programme not just to growth but to the buzzword 'financial inclusion'. They explained it will make funds and finance available to 'the most vulnerable groups, including micro, small and medium sized enterprises' (Johnson, 2014).

The loans were financed via the Central Bank of Nigeria's (CBN) N220bn Micro, Small and Medium Entrepreneur Development Fund (MSMEDF) scheme, for which Oyo signed a Memorandum of Understanding with the CBN in July 2014 and formed part of the CBN's 2012 National Financial Inclusion Strategy. This allowed Ajimobi to enact political empowerment programmes to build his party support base, whilst simultaneously meeting the current donor priorities such as the World Bank's Universal Financial Access goal, for which Nigeria was a target country (Bank, 2015). Ajimobi announced that the state government had its own target of $80 \%$ financial inclusion by 2020 (Johnson, 2014). The external financing of the loan programme also served a variety of purposes: maintaining the financial probity of the state government and opening up non-budgetary fiscal space for Ajimobi to respond to political demands that contradicted his stated principles. This scheme shows how the Governor found ways to deliver empowerment within the normative boundaries of programmatic politics.

Whilst the reports on Channels TV was framed in line with the Lagos Model of programmatic politics the brute material facts of the programme overrode the uniform but superficial coding of the project as anything but patronage. The traders are reported as coming from 'across the 33 Local Government Areas of Oyo State' to benefit from the governor's 'Economic Empowerment Programme.' Ajimobi referred to the loans as his 'own stomach infrastructure' (Channels TV, 2014). The overall programme - its aesthetics and its distributive party-political logic - fitted seamlessly into the existing ideas of what 'empowerment' looks like, established over years of political performance by parties of all 
stripes that ordinary Nigerians are familiar with both from lived experience and TV and newspaper reports. The loud-speakers, the dancing, the marquees, the photo opportunities were all familiar motifs of the generous governor sharing the dividends of democracy with the people. This opened up the realm of verbal discourse to serve alternative ends and audiences via intentional ambivalence. It gave space in Ajimobi's speech and the contributions of government and $\mathrm{CBN}$ officials to an alternative interpretation: an interpretation of the event as a tool for financial inclusion and other donor-endorsed programmatic goals. Overall the empowerment event was a way for Ajimobi to engage in patronage, as in the distribution of immediate economic benefits, and demonstrate 'human face' whilst maintaining the rupture from amala politics as vote buying or reckless giving.

Amala, vote-buying or empowerment?

In addition to the stadium-filling empowerment event broadcast on television, there was a second series of ACM empowerment events hosted by Ajimobi's wife. These also involved inviting members of associations to campaign sessions where they received material goods including minibuses, APC-branded cloth, motorbikes and transformers, and pledged their support for the party. Between March $16^{\text {th }}$ and April $7^{\text {th }}, 2015,16$ groups, comprising market, religious and youth associations attended small private rallies with Florence Ajimobi. However, without the framing of the CBN financial inclusion agenda, these distributions were harder for the progressives to clearly distinguish from amala politics and they were not advertised in the same way as the loans. In fact, the only online sources of evidence for such gifts was on Florence Ajimobi's Facebook page and used Florence Ajimobi as their figurehead, rather than the Governor himself. These smaller empowerment events were so explicitly linked to the party - through the branded APC cloth that was given out, for example - that they were best kept out of sight of external audiences. Nonetheless, in my interview with him, the campaign manager of the ACM confirmed that it was state government money that went towards financing these benefits and that they were directed towards those who had signed up to support the APC.

The ambivalence and discomfort of this blurring was reflected in the campaign manager's account of the schemes. He explained:

"Oga succeeded... [pauses] in giving out about 80 to 100 buses. To all these associations. So, each association that has the resources, they will give them buses." I put it to Ade that this was a form of vote buying, which he denied; 'No, it's not they are buying votes! Because we did it before the election [his voice grows] we are not buying vote! It is just like responsibility of government to the people. ... We don't need to buy votes. It's because they were convinced. ${ }^{x}$

The association leaders I spoke to approved of the Ajumose Coalition Movement process and were comfortable with the quid pro quo involved. The Babaloja of a major market in central Ibadan who helped negotiate the deal noted that they were successful in their demands because the government 'needed our votes'. Many of the groups that had benefitted made public statements in favour of Ajimobi's second term and the large umbrella groups organized an appreciation rally in early 2015 to show their support for Ajimobi (Adeniyi, 2014). For example the Spokesman for the Oyo Joint Traders Association announced at a rally on 9 February 2015 that the association was endorsing Ajimobi for a second term ("Mrs Ajimobi seeks traders' support for husband, APC candidates," 2015). From interviews with other traders there was evidence that even just the news of the scheme had a positive effect on Ajimobi's reputation. They hoped that perhaps when Ajimobi got back into power he would undertake another round of loans and they would benefit ${ }^{\mathrm{xi}}$. 
Moreover, the ACM provided targeted access to Ajimobi himself, who otherwise was seen as a remote Governor. The campaign manager went back to each member group once a month to meet with the chairmen and executive for 'interactive sessions' where information flowed both ways. The campaign manager explained that he would 'educate them about government policies' and they would tell him 'what are those things that they want government to do for them. ${ }^{\text {, xii }}$ Thus beyond its material effects, the loan package showed that, in contrast to his image as 'out of touch', Ajimobi was a man who could be negotiated with. As predicted by Schaffer and Schedler's (2007, p. 17) work on vote-buying, with the loans serving "as pieces of information that reveal the positive personal qualities of the giver, such as generosity, politeness, responsiveness, and respect". Just as the APC derived legitimacy by promising the progress that their populist predecessors failed to provide, they were nonetheless evaluated against the memory of an established repertoire of distributive and associational practices. Even as Ajimobi resisted these, familiar idioms such as 'empowerment' still served as aesthetic resources through which his own programmes could be linked with immediate benefits.

Just as with the loans to traders scheme, photos of the federal government's TraderMoni show women dancing in bright yellow branded t-shirts whilst clutching loan documents. The parallels extend to debates about vote-buying at the national level, with rival accounts of the conditions under which such distribution would be legitimate. The chairman of Transparency International Nigeria described TraderMoni as "voter inducement" due to its proximity to the 2019 presidential election and argued that was equivalent to the President using public funds for his re-election campaign. Moreover, seeing as it was not in the APC manifesto the President lacked a mandate for using state funds in such a way. PDP big-shot and Senate President Bukola Saraki also opposed the scheme but on different ground. The distribution of loans was not problematic per se but the timing brought it into question: "[they] should have been doing it since 2015." Moreover, the use of party networks to distribute the funds was not a problem in itself, but rather its partiality. As he said, "At least, if you're going and since it is Nigerian money he should have women leaders of all the political parties because the money belongs to Nigeria." ("Saraki to FG," 2018) As in Oyo, officials, this time at the Bank of Industry, defended TraderMoni on the grounds of financial inclusion.

\section{RE-READING NIGERIAN POLITICS: BEYOND PROGRAMMATIC VERSUS PATRIMONIAL POLITICS}

This analysis has implications not only for Oyo state but for how we read politics in Nigeria more generally. Within the dominant understanding of Nigerian politics the phenomenon of giving loans to traders would be understood as programmatic politics being pulled in the direction of patrimonialism. On this reading, both Ajimobi's deviation from the Lagos Model in Oyo state and the last-minute introduction of TraderMoni by Osinbajo and Buhari, are cases of upstanding leaders having to go against their principles and engage in patronage. Indeed, this is largely the story that Lagos Model politicians told about their own political maneuvers. However, this article suggests that this is not the only lens through which to make sense of political contestation in Nigeria. Rather than a tale of 'corruption fights back' (Adebanwi and Obadare, 2011) or the triumph of the patrimonial under a neopatrimonial façade, it demonstrates the partial ways in which popular conceptions of good governance can be reasserted against technocratic visions that people see as non-transparent, inaccessible and distant. The Oyo 2015 election and the story of $21^{\text {st }}$ century Nigerian politics more generally can thus be understood as contestation over what counts as legitimate distribution. 
As such the discussion presented in this article challenges recent work on what politics should look like in Africa. Bleck and Van de Walle analyse news reports in the lead up to elections in nine Africans countries, including Nigeria, to argue that much of the current political discourse concerns issues "over which there is broad agreement." (2013, p. 1397) These 'valence issues' stand in contrast to position statements whereby concrete plans of action are set out differentiating the parties from each other: "disagreement focuses not on the ultimate objective of policy about which there is consensus, but instead on how to attain desired goals and who is more likely to succeed in doing so." (Bleck and van de Walle, 2013, p. 1397) On this view, democratic accountability is undermined because the majority of statements made by Nigerian contenders for state office pertain to "issues on which everyone agrees" such as anti-corruption and development. It is hoped that with greater institutionalization parties in Africa will move towards not only programmatic politics, but a gold-standard of politics based on position statement. The implicit claim is that voters should get to choose between distinct policy approaches to achieve these universally agreed goals.

No doubt, such practical policy debates are an important ingredient of political contestation. However, the case of Oyo state shows that this conception of good politics rules out important meta-questions. Given the scale of Bleck and van de Walle's nine country study, it inevitably misses the ways in which discourse that they describe as valence nonetheless represents contestation over the larger question of how development should be understood and what the appropriate boundaries of government actions are. For example, they claim that "actors cannot take a stand "against development," and, therefore, conversations about economic development and poverty alleviation typically involve posturing for credibility rather than substantive disagreements." (Bleck and van de Walle, 2013, p. 1405) But the analysis above shows that politicians contest the meaning of development via terms like "people-centric", "human face" and "stomach infrastructure". Whilst these terms may at first glance may appear to be blandly positive 'valence terms' - reflect deeper and more fundamental underlying disagreements. Much of this discussion can be traced back fundamental debates over what forms of distribution are legitimate: debates which are obscured if we naturalise the conceptual framework of programmatic versus patrimonial politics as somehow existing prior to politics.

Building on the work of Herbert Kitschelt (2007), Bleck and van de Walle argue that valence issues tend to dominate in clientelistic systems because politicians tend to "distinguish themselves through their ability to deliver tangible benefits to constituents." (2013, p. 1397) Indeed, they recognize that structural features of African democratic systems lead 'programmatic' commitments to be frustratingly intangible. African leaders face uncertainty stemming from the volatility of their insertion into the global economy, dependence on sometimes fleeting donor agendas and a wider under-institutionalisation of state power. Whilst they link this to the neo-classical need to make credible policy commitments, similar observations have also been linked to the status of many African states as 'choiceless democracies' on the grounds that significant policy options are foreclosed by their dependence on not only donors but how they are perceived by international capital (Mkandawire, 1998, 2009). Emerging development agendas like the Sustainable Development Goals which put private sector actors at their heart rely on theories of change where the link between government spending and the poor is increasingly truncated (Bayliss and Waeyenberge, 2018, p. 580). Indeed, Lagos State's flagship projects include privatelybuilt infrastructure, such as Eko Atlantic and the toll-maintained Lekki Expressway, which symbolize ambitious programmes of modernisation whilst nonetheless excluding many on the ability to pay. For voters in Oyo weighing up the promise of programmatic politics under the 
Lagos Model, they might be forgiven for preferring what Bleck and van de Walle dismiss as 'tangible benefits'.

\section{CONCLUSION:}

Politics is indeed about distribution, but encompasses more than simply what public goods the state should provide and how. It encompasses meta-level questions about what sort of politics is good politics and the standards and norms against which people, parties and policies should be judged. By suspending the long-standing scholarly instinct to read Nigerian politics in terms of programmatic versus patrimonial politics we open up the possibility that democracy in Africa is doing much more interesting things than simply operating as a feedback mechanism for the performance of politicians against set criteria. Unlike the assumptions of much of the current quantitative literature, there are substantive political struggles that go beyond 'public goods good, private goods bad'. The scholarly framing of programmatic versus patrimonial politics obscures the essentially contested nature of what counts as legitimate distribution. This article has shown that the idea of patrimonial versus programmatic politics does not stand outside of politics but is in itself a politically constructed distinction. In adopting it a priori as scholars we commit ourselves to seeing the world through the eyes of a specific, often elite, constituency that makes up only part of the rich landscape of normative political contestation in Nigeria.

Much of the existing literature conceives of African countries as somewhere along a teleological path leading to convergence on a narrowly conceived vision of good politics that works for development. In a context of continuing high level of poverty and deprivation on the continent some would say that this level of prescriptiveness is justified by the urgency of the task African politicians must contend with. On a continent where two thirds of people lack access to clean water the need for more and better public goods provision could be taken to be a no-brainer. However, contrary to those who see both as valence terms, 'good politics' and 'development' are both contested terms in southwest Nigeria and beyond. If it was true that developmental challenges induced technocratic consensus then we wouldn't see the profound debates and paradigm shifts that characterise the development industry - as evidence in the revolution in social protection and the rise of cash transfers over recent decades. The same question, posed to an academic audience by Joe Hanlon in 2004, is essentially at the heart of ongoing political contestation in Nigeria today: is it possible to just give money to the poor? 


\section{REFERENCES}

Adebanwi, W., 2014. Yorùbá Elites and Ethnic Politics in Nigeria: Obáfemi Awólowo and Corporate Agency. Cambridge University Press, New York, NY.

Adebanwi, W., 2005. The Carpenter's Revolt: Youth, Violence and the Reinvention of Culture in Nigeria. J. Mod. Afr. Stud. 43, 339-365.

Adekanmbi, D., 2015. Why Ajimobi'll be re-elected - Alabi. Niger. Trib.

Adekanmbi, D., 2013. Lawmaker empowers constituents with working tools. Tribune.

Adeniyi, A., 2014. Traders endorse Ajimobi for second term. The Nation.

Adeyemo, A., 2008. The Godfather Finally Sleeps. ThisDay.

Africa: Lessons from Lagos, 2012. . Financ. Times.

Agbaje, A., 2002. Personal rule and regional politics: Ibadan under military regimes, 1986-1996, in: Money, Struggles and City Life: Devaluation in Ibadan and Other Urban Cetnres in Southern Nigeria 1886-1996. Heinemann, Portsmouth NH.

Ajayi, O., 2014. Oyo 2015: Why Ajimobi should start packing now — Lekan Balogun. Vanguard News.

Akinrefon, D., 2014. Ayo Fayose wins Ekiti elections. Vanguard News.

Amusat, K., 2015. Who will Oyo elect as its new governor? ThisDay.

Animasawun, G.A., 2013. Godfatherism in Nigeria's Fourth Republic: The Pyramid of Violence and Political Insecurity in Ibadan, Oyo-State, Nigeria (No. 27), IFRA-Nigeria E-Papers series. IFRA-Nigeria, Nigeria.

Atoyebi, O., 2014. Criticism against Ajimobi frivolous -Attorney-General. Punch.

Bank, 2015. Putting the tools in place for greater financial inclusion in Nigeria. World Bank. URL http://www.worldbank.org/en/news/feature/2015/08/20/putting-the-tools-in-place-for-greaterfinancial-inclusion-in-nigeria (accessed 11.21.16).

Barber, K., 1995. Money, self-realization and the person in Yorùbá texts, in: Money Matters : Instability, Values and Social Payments in the Modern History of West African Communities. Heinemann, Portsmouth NH, pp. 205-224.

Bayliss, K., Waeyenberge, E.V., 2018. Unpacking the Public Private Partnership Revival. J. Dev. Stud. 54, 577-593. https://doi.org/10.1080/00220388.2017.1303671

Bleck, J., van de Walle, N., 2013. Valence Issues in African Elections: Navigating Uncertainty and the Weight of the Past. Comp. Polit. Stud. 46, 1394-1421. https://doi.org/10.1177/0010414012453448

Booth, D., Golooba-Mutebi, F., 2012. Developmental patrimonialism? The case of Rwanda. Afr. Aff. 111, 379-403. https://doi.org/10.1093/afraf/ads026

Bratton, M., van de Walle, N., 1994. Neopatrimonial Regimes and Political Transitions in Africa. World Polit. 46, 453-489. https://doi.org/10.2307/2950715

Channels TV, 2014. 6,000 Traders Get Interest-Free Loans In Oyo State. Ibadan.

Cheeseman, N., de Gramont, D., 2017. Managing a mega-city: learning the lessons from Lagos. Oxf. Rev. Econ. Policy 33, 457-477. https://doi.org/10.1093/oxrep/grx033

de Gramont, D., 2015. Governing Lagos: Unlocking the Politics of Reform. Carnegie Endow. Int. Peace.

Esan, A., 2012. Oyo minority leader counsels Ajimobi on 2013 Budget. Natl. Mirror.

Fourchard, L., 2011. Lagos, Koolhaas and Partisan Politics in Nigeria. Int. J. Urban Reg. Res. 35, 4056. https://doi.org/10.1111/j.1468-2427.2010.00938.x

Gadjanova, E., 2017. Electoral clientelism as status affirmation in Africa: evidence from Ghana. J. Mod. Afr. Stud. 55, 593-621. https://doi.org/10.1017/S0022278X17000416

Grindle, M.S., 2004. Good Enough Governance: Poverty Reduction and Reform in Developing Countries. Governance 17, 525-548. https://doi.org/10.1111/j.0952-1895.2004.00256.x

Guyer, J.I. (Ed.), 1995. Money Matters: Instability, Values and Social Payments in the Modern History of West African Communities. James Currey, Portsmouth, NH; London.

Hanlon, J., 2004. It is Possible to Just Give Money to the Poor. Dev. Change 35, 375-383. https://doi.org/10.1111/j.1467-7660.2004.00356.x

Hoffmann, L., Nolte, I., 2013. The Roots of Neopatrimonialism: Opposition Politics and Popular Consent in Southwest Nigeria, in: Democracy and Prebendalism in Nigeria: Critical Interpretations. Palgrave Macmillan, New York, NY, pp. 25-52. 
Hossain, N., 2007. The Politics of What Works: The Case of the Vulnerable Group Development Programme in Bangladesh (SSRN Scholarly Paper No. ID 1629297). Social Science Research Network, Rochester, NY.

Husaini, S., 2018. Testing Loyalty: Electoral Politicking between stomach infrastructure, mai gaskiya, and moral competence, in: Normative Politics in Africa Workshop. Queen Elizabeth House, Oxford.

Ifowodo, O., 2014. Ekiti Verdict 2014: The Apotheosis of Adedibu. Vanguard News.

International: A rare good man; Nigeria's business capital, 2011. . The Economist 55.

Jegede, J., 2013. Ajimobi promises Oyo traders N300 million interest-free loan. Prem. Times.

Johnson, T., 2014. Ajimobi gives N300m to traders. The Nation. URL http://thenationonlineng.net/new/ajimobi-gives-n300m-traders/ (accessed 1.13.15).

Kelsall, T., 2011. Going with the Grain in African Development? Dev. Policy Rev. 29, s223-s251. https://doi.org/10.1111/j.1467-7679.2011.00527.x

Khan, M.H., 2005. Markets, states and democracy: Patron-client networks and the case for democracy in developing countries. Democratization 12, 704-724. https://doi.org/10.1080/13510340500322157

Kitschelt, H., 2007. Party Systems, in: Boix, C., Stokes, S.C. (Eds.), The Oxford Handbook of Comparative Politics. Oxford University Press, Oxford, UK.

Kramon, E., 2017. Money for Votes: The Causes and Consequences of Electoral Clientelism in Africa. Cambridge University Press.

Layonu, T.A., 2003. Adelabuism : politics of Adegoke Adelabu, the legendary leader of Ibadan people. Media Report Projects, Ibadan, Nigeria.

LeBas, A., Cheeseman, N., 2013. The Lagos Experiment: Services Delivery, Tax Collection, and Popular Attitudes (SSRN Scholarly Paper No. ID 2253686). Social Science Research Network, Rochester, NY.

Lindberg, S.I., 2013. Mapping accountability: core concept and subtypes. Int. Rev. Adm. Sci. 79, 202-226. https://doi.org/10.1177/0020852313477761

Lindberg, S.I., 2010. What accountability pressures do MPs in Africa face and how do they respond? Evidence from Ghana<a href="\#fn01a" $>*</ a>$. J. Mod. Afr. Stud. 48, 117-142. https://doi.org/10.1017/S0022278X09990243

Mkandawire, T., 2009. Institutional Monocropping and Monotasking in Africa (Democracy, Governance and Well-Being Programme Paper No. 1). United Nations Research Institute for Social Development, Geneva.

Mkandawire, T., 1998. Crisis management and the making of 'choiceless democracies' in Africa, in: Joseph, R.A. (Ed.), State, Conflict, and Democracy in Africa. Lynne Rienner Pub, Boulder, Colo.

Mrs Ajimobi seeks traders' support for husband, APC candidates, 2015. . News Agency Niger.

Mueller, L., 2018. Personal Politics without Clientelism? Interpreting Citizen-Politician Contact in Africa. Afr. Stud. Rev. 61, 28-54. https://doi.org/10.1017/asr.2017.131

Nic Cheeseman, 2014. Politics Meets Policies: The Emergence of Programmatic Political Parties. IDEAS, Stockholm.

Ogunyemi, D., 2015. How Ajimobi Broke Second Term Jinx in Oyo. Dly. Trust Abuja.

Oladele, B., 2014. States lack autonomy says Ajimobi. The Nation.

Olivier de Sardan, J.-P., 1999. A moral economy of corruption in Africa? J. Mod. Afr. Stud. 37, 2552.

Omobowale, A., 2008. Clientelism and social structure : an analysis of patronage in Yoruba social thought. Afr. Spectr. 43.

Omobowale, A., Olutayo, A., 2010. Political Clientelism and Rural Development in South-Western Nigeria. Africa 80.

Omobowale, A., Olutayo, A., 2007. Chief Lamidi Adedibu and Patronage Politics in Nigeria. J. Mod. Afr. Stud. 45, 425-446.

OSG Website, 2015. Full text of Governor Ajimobi's inaugural speech. Website Oyo State Gov. URL http://www.oyostate.gov.ng/full-text-of-governor-ajimobis-inaugural-speech/ (accessed 4.14.16). 
OSG Website, 2014. Ajimobi raises alarm over dwindling allocation to states. Oyo State Gov. Website. URL http://www.oyostate.gov.ng/ajimobi-raises-alarm-over-dwindling-allocationto-states/ (accessed 11.5.15).

OSG Website, 2013. Text of Gov Ajimobi’s Budget Speech 2013. Website Oyo State Gov. URL http://www.oyostate.gov.ng/text-of-gov-ajimobis-budget-speech/ (accessed 2.9.15).

Oxford Business Group, 2013. Opening doors to investment [WWW Document]. URL https://www.oxfordbusinessgroup.com/overview/opening-doors-investment-state-set-servenew-investors-it-streamlines-procedures-and-improves (accessed 11.2.16).

Paller, J., 2014. Informal Institutions and Personal Rule in Urban Ghana. Afr. Stud. Rev. 57, 123-142. https://doi.org/10.1017/asr.2014.95

Peel, J.D.Y., 1983. Ijeshas and Nigerians : The Incorporation of a Yoruba Kingdom 1890-1970s. Cambridge University Press,.

Sanches, E.R., 2018. Party Systems in Young Democracies : Varieties of institutionalization in SubSaharan Africa. Routledge. https://doi.org/10.4324/9781315200354

Saraki to FG: Involve opposition in Trader moni or scrap it, 2018. . Trib. Online. URL https://www.tribuneonlineng.com/176312/ (accessed 2.5.19).

Schaffer, F.C., Schedler, A., 2007. What is vote-buying?, in: Schaffer, F.C. (Ed.), Elections for Sale: The Causes and Consequences of Vote Buying. Lynne Rienner Publishers, Boulder, Colo.

Taiwo, O., 2014. Politics of poverty alleviation schemes. Tribune.

The APC Government in Oyo State is gone - Senator Lekan Balogun, 2014. . The Punch.

Timothy, G., 2008. Adedibu - Who takes Over the Garrison Command? Leadership.

Tinubu, Akande, Rochas rejoices with Ibadan on projects Commissioning., 2013. . The Guardian.

TraderMoni is vote buying, says Transparency International, 2019. . Punch Newsp.

Ugwuanyi, S., 2014. Fayemi speaks on achievements during his tenure as Ekiti Governor. Dly. Post Niger.

Vicente, P.C., Wantchekon, L., 2009. Clientelism and vote buying: lessons from field experiments in African elections. Oxf. Rev. Econ. Policy 25, 292-305. https://doi.org/10.1093/oxrep/grp018

Watson, R., 2000. Murder and the Political Body in Early Colonial Ibadan. Africa 70, 25-48. https://doi.org/10.3366/afr.2000.70.1.25

Watson, R., 1998. The Cloth of Field of Gold: Material Culture and Civic Power in Colonial Ibadan. J. Hist. Sociol. 11, 461-491. https://doi.org/10.1111/1467-6443.00073

World Bank, 2016. Making Politics Work for Development: Harnessing Transparency and Citizen Engagement. The World Bank. https://doi.org/10.1596/978-1-4648-0771-8 


\section{NOTES}

i Quoted in "Oyo: Why our people are angry with Gov Ajimobi — Teslim Folarin" Vanguard News, December 222014.

ii Quoted in Hanlon 2004 pg.375

iii I-28 Member of Ajimobi's Campaign Team, Ibadan, 26/05/2015

iv I-33 Staff member of DAWN Commission, Ibadan 05/06/2015

v Adedibu's first protégé Rashidi Ladoja was Governor for the PDP between 2003-

2006 before becoming estranged from Adedibu. He contested the 2015 election on the

Accord ticket. The two other major rivals to Ajimobi were also former protégés of Adedibu:

Teslim Folarin (PDP) and former governor Christopher Akala (Labour Party).

vi I-17 Special Adviser to the Governor, Ibadan, 22/04/2015

vii When Ajimobi first came to power, the monthly federal allocation to Oyo State was approximately N4.2bn and the cost of wages and salaries was N2.9bn. Due to low oil prices, by November 2014 revenue fell to N3.2bn whilst salaries grew to N5bn, leaving a monthly deficit of N1.8bn (OSG Website, 2014).

viii AJ1-1 and AJ1-2 Staff of Ajumose Vocational Training Centre, Ibadan 21/05/2015.

ix CLG 4-1 Local Government Caretaker Chairman, Ibadan 05/08/2015

x $\quad$ I-49

xi CM2-1 Focus Group with traders, Ibadan 07/07/2015

xii12 1-49 Member of Ajimobi's Campaign, Ibadan 06/08/2015 